\section{Residual Nitrogen and Kill Date Effects on Winter Cover Crop Growth and Nitrogen Content in a Vegetable Production System}

\author{
Gary R. Cline ${ }^{1}$ and \\ Anthony F. Silvernail ${ }^{2}$
}

ADPMIALA- winter cover crops, nitrogen fixation, legume cover crops, no-till vegetables

Summary. A 4-year field experiment examined how monoculture and biculture winter cover crops were affected by prior inorganic nitrogen (N) fertilization of sweet corn ( $Z e a$ mays) and by kill dates associated with tillage methods. Hairy vetch (Vicia villosa) biomass production and $\mathrm{N}$ content remained relatively constant with $(\mathrm{N}+)$ or without (N0) prior $\mathrm{N}$ application. In $\mathrm{N}+$ treatments, biomass production of winter rye (Secale cereale) and a vetch-rye biculture were significantly greater than vetch biomass production. Rye responded to prior $\mathbf{N}$ fertilization and recovered $\mathrm{N}$ from residual inorganic $\mathrm{N}$ fertilizer at an average annual rate of $30 \mathrm{~kg} \cdot \mathrm{ha}^{-1}(27 \mathrm{lb} /$ acre $)$, excluding contributions of roots. Nitrogen contents of vetch and biculture cover crops were similar in most years and were significantly greater than those of rye. Nitrogen contents in vetch and biculture treatments were not increased by the residual inorganic $\mathrm{N}$

Community Research Service, Kentucky State University, Frankfort, KY 40601.

This research was funded by a USDA., CSREES grant to Kentucky State University under agreement KY.X10-94-21P. The cost of publishing this paper was defrayed in part by the payment of page charges. Under postal regulations, this paper must be hereby marked advertisement solely to indicate this fact. The cost of publishing this paper was defrayed in part by the payment of page charges. Under postal regulations, this paper therefore must be hereby marked advertisement solely to indicate this fact.

${ }^{1}$ Principal investigator.

${ }^{2}$ Coinvestigator. fertilizer addition of the $\mathrm{N}+$ treatment. In the biculture treatment prior $\mathrm{N}$ application increased total biomass production but decreased the percentage of vetch biomass. Monoculture vetch biomass production was significantly increased by delaying cover crop kill dates for $\mathbf{8}$ days in mid-May. However, such delays also significantly lowered vetch foliar $\mathbf{N}$ concentrations and consequently did not significantly affect vetch $\mathbf{N}$ content. No significant effects of delays on rye or biculture cover crops were detected. It was concluded that prior fertilization of sweet corn with inorganic $\mathbf{N}$ affected various cover crops differently and that delaying vetch kill dates 8 days increased biomass production but did not affect N content.

S ustainable cropping practices such as the use of legume cover crops and conservation tillage are not used extensively by vegetable growers (Brumfield, 1996; Drost et al., 1997; Johnson and Hoyt, 1999; Roberts et al., 1999). However, sustainable production of vegetables is expected to increase in accordance with market demand (Brumfield, 1996), and research is needed to resolve uncertainties of vegetable growers about using no-tillage and legume cover crops (Hanson et al., 1995; Hoyt et al., 1994).

Use of small grains as winter cover crops is a sustainable agricultural practice that can increase levels of soil organic matter while reducing soil erosion and nutrient losses (Kuo et al., 1997a; Peet, 1996). Legume winter cover crops have the added benefit of providing fixed dinitrogen gas $\left(\mathrm{N}_{2}\right)$ to succeeding cash crops (Abdul-Baki et al., 1997). Most research on using legumes in rotations has been conducted with agronomic and forage crops, and legumes are not used as extensively by vegetable growers (Abdul-Baki et al., 1996b; Singogo et al., 1996). Because dry matter production and carbon to nitrogen $(\mathrm{C}: \mathrm{N})$ ratios are often greater for small grains than legumes, small grains may be superior to legumes in maintaining or increasing levels of soil organic matter (Kuo etal., 1997a, 1997b; Peet, 1996). Small grains also recover more residual soil $\mathrm{N}$ than legumes (Shipley et al., 1992). Winter rye is the most common small grain winter cover crop in 
the central and southern U.S. corn belt (Bollero and Bullock, 1994), whereas hairy vetch is the most productive legume winter cover crop in many areas of the United States, including Kentucky (Decker et al., 1994; Ebelhar et al., 1984; Holderbaum et al., 1990; Rasnake et al., 1996).

Bicultures of legume and small grain cover crops combine characteristics of each and often produce more biomass than monocultures (Clark et al., 1997; Rannells and Wagger, 1996). In bicultures, rye is an excellent companion cover crop for hairy vetch because it provides vertical support for growth of vetch, enabling the more prostrate vetch to compete more effectively (Schonbeck et al., 1995). The species composition of cover crop bicultures can be altered by location, kill date, and climatic factors (Clark et al., 1994; Holderbaum et al., 1990; Rannells and Wagger, 1996, 1997). Clark et al. (1994) reported that differences in biculture species composition between two sites may have been due to differences in soil $\mathrm{N}$ availability. In traditional studies with agronomic crops, effects of cover crops and inorganic $\mathrm{N}$ fertilizer have been examined on cash crops, but little emphasis has been placed on determining effects of prior $\mathrm{N}$ fertilization and soil $\mathrm{N}$ availability on growth of cover crops, especially biculture cover crops (Blevins et al., 1990; Clark et al., 1995, 1997; Decker et al., 1994; Ebelhar et al., 1984). Such information would be useful in predicting biomass production, species composition (bicultures), and $\mathrm{N}$ contents of cover crops including their effects on succeeding cash crops.

Conservation tillage appears to be acceptable for vegetable production since vegetable yields obtained using such systems have been greater or equivalent to yields produced using conventional methods in some studies (Abdul-Baki et al., 1996a, 1996b, 1997; Abdul-Baki and Teasdale, 1997; Hoyt, 1999; Infante and Morse, 1996; Scarphol and Corey, 1987; Schonbeck et al., 1995) . However, adverse effects of conservation tillage on vegetable yields have also been reported (Hoyt, 1999; Hoyt and Walgenbach, 1995; Knavel and Herron, 1986; Knavel et al., 1977; Mwaja et al., 1996; Peterson et al., 1985). In no-till systems, vegetables may be planted soon after killing cover crops (Abdul-Baki et al., 1996b), whereas a delay of at least 1 to 2 weeks, and often 4 weeks, is recommended following tillage (Hoyt et al., 1994). Beneficial effects of delayed kill dates on cover crops have been described for agronomic crops (Clark et al., 1994, 1995, 1997), but information is lacking for summer vegetables that are planted later in the season than most agronomic crops. For such vegetables, cover crops may be grown for a longer time in the spring, and kill date effects on cover crop biomass production and $\mathrm{N}$ content may differ from those determined earlier in the spring for agronomic crops.

The objectives of this study were to 1 ) determine biomass production and N content of rye, vetch, and vetch/ rye biculture winter cover crops in a vegetable cropping system including watermelon (Citrullus lanatus) and sweet corn (Zea mays), 2) determine how winter cover crops are affected by differences in soil $\mathrm{N}$ availability, and 3 ) determine the effects of cover crop kill dates associated with tilled and no-till vegetable production on cover crop biomass production and $\mathrm{N}$ content.

\section{Materials and methods}

The experiment was conducted from September to May for 4 years following sweet corn and preceding watermelon at the Kentucky State University Research Farm in Frankfort, KY. A 2 (ximesx) 3 (ximesex) 2 factorial, split-plot, randomized complete block experimental design was used with three replications. Main plots were tilled and no-till treatments of corn and watermelon, and subplots consisted of winter cover crop treatments and $\mathrm{N}$ treatments randomized within main plots. Cover crops of hairy vetch and winter rye were planted with a notill drill at seeding rates of 45 and 120 $\mathrm{kg} \cdot \mathrm{ha}^{-1}$ (40 and $107 \mathrm{lb} /$ acre), respectively. A third cover crop consisted of a biculture of vetch and rye seeded at $50 \%$ of monoculture rates. The $\mathrm{N}$ treatments were the preplant addition of ammonium nitrate $\left(\mathrm{NH}_{4} \mathrm{NO}_{3}\right)(\mathrm{N}+)$ and no $\mathrm{NH}_{4} \mathrm{NO}_{3}(\mathrm{~N} 0)$ to the preceding crop of sweet corn in early June at a rate of $125 \mathrm{~kg} \cdot \mathrm{ha}^{-1}(112 \mathrm{lb} /$ acre $)$ of $\mathrm{N}$, followed by a sidedressing of 75 $\mathrm{kg} \cdot \mathrm{ha}^{-1}(67 \mathrm{lb} /$ acre $)$ of $\mathrm{N} 4$ weeks later. Subplots measured 5 \{ximex\} $5 \mathrm{~m}$ (16 (ximesx) $16 \mathrm{ft}$ ) in size and were separated by a minimum distance of $1 \mathrm{~m}(3.2 \mathrm{ft})$. In 1994, 1996, and 1998, the experimental was conducted at a site con- taining Elk silt loam soil (fine-silty, mixed, mesic, Ultic Hapludalfs) with a $\mathrm{pH}$ of 6.4. An immediately adjacent site with similar soil was used in 1995.

Vetch was inoculated with appropriate rhizobia bacteria before planting, and winter cover crops were drilled on 10, 20, 25, and 22 Sept. 1993, 1994, 1995, and 1997, respectively. Cover crops were identified by the year of their maturation the following spring. In tilled treatments cover crops were incorporated into the soil with a moldboard plow on $19,23,22$, and 21 May in years 1994, 1995, 1996, and 1998, respectively. This was done 2 weeks before planting watermelon to reduce levels of toxins associated with cover crop decomposition and to allow settling of the soil (Rowell et al., 1998). In no-till treatments cover crops were desiccated by spraying with (a.i.) $0.35 \mathrm{~kg} \cdot \mathrm{ha}^{-1}(0.3 \mathrm{lb} /$ acre $)$ paraquat (1,1-dimethyl4,4-bipyridiniumion) on $27,30,30$, and 29 May 1994, 1995, 1996, and 1998, respectively. Thus, in all years except 1998, cover crops grew an average of $8 \mathrm{~d}$ longer in no-till treatments than in tilled treatments under optimal warm spring growing conditions. On kill dates vetch was in the vegetative to early-flowering stage in the tilled treatment and was flowering in the no-till treatment. Rye was in the flowering or late-flowering stages in both tillage treatments. One day before kill dates four subsamples of aboveground cover crops were removed from a total area of $0.5 \mathrm{~m}^{2}\left(5.4 \mathrm{ft}^{2}\right)$ in each subplot and combined. In the biculture treatment, vetch and rye plant material were separated. After drying at $65^{\circ} \mathrm{C}\left(149^{\circ} \mathrm{F}\right)$ for $48 \mathrm{~h}$, the samples were weighed. The samples were then ground to a particle size about $0.4 \mathrm{~mm}$ (0.016 inch) and analyzed for total $\mathrm{N}$ using an $\mathrm{N}$ analyzer (model FP-228; Leco Corp., St Joseph, Mich.).

Plant-available soil $\mathrm{N}$ was measured following sweet corn at the time of planting cover crops. In each subplot three soil subsamples were collected to a depth of $15 \mathrm{~cm}$ (5.9 inch) and combined. After air-drying for 48 $\mathrm{h}$, soil extracts were obtained by shaking $5 \mathrm{~g}(0.18 \mathrm{oz})$ of soil in $50 \mathrm{~mL}$ ( 1.7 $\mathrm{oz})$ of $2 \mathrm{~m}$ potassium chloride $(\mathrm{KCl})$ for $1 \mathrm{~h}$ and filtering using Whatman 42 filter paper. Ammonium and nitrate levels in soil extracts were determined colorimetrically using the indophenol blue and Cd reduction methods, respectively, and their sum was consid- 
Table 1. Residual soil nitrogen ( $\mathbf{N})$ available to cover crops in $\mathbf{N}$ fertilization treatments of sweet corn.

\begin{tabular}{|c|c|c|c|}
\hline \multirow[b]{2}{*}{$\underline{N}$ treatment $^{\mathbf{y}}$} & \multicolumn{3}{|c|}{ Residual available soil N (mg.kg $\left.{ }^{-1}\right)^{z}$} \\
\hline & Rye & Vetch & Biculture \\
\hline \multicolumn{4}{|l|}{1995} \\
\hline No & $11.2 \mathrm{~b}^{\mathrm{x}}$ & $18.7 \mathrm{a}$ & $17.9 \mathrm{~b}$ \\
\hline $\mathrm{N}+$ & $18.4 \mathrm{a}$ & $25.2 \mathrm{a}$ & $27.7 \mathrm{a}$ \\
\hline \multicolumn{4}{|l|}{1996} \\
\hline No & $10.4 \mathrm{~b}$ & $13.2 \mathrm{~b}$ & $12.4 \mathrm{a}$ \\
\hline $\mathrm{N}+$ & $16.8 \mathrm{a}$ & $38.4 \mathrm{a}$ & $21.7 \mathrm{a}$ \\
\hline \multicolumn{4}{|l|}{1998} \\
\hline No & $10.2 \mathrm{~b}$ & $16.2 \mathrm{~b}$ & $15.2 \mathrm{~b}$ \\
\hline $\mathrm{N}+$ & $31.1 \mathrm{a}$ & $65.3 \mathrm{a}$ & 40.7 a \\
\hline
\end{tabular}

${ }^{\mathrm{z}} 1.0 \mathrm{mg} \cdot \mathrm{kg}^{-1}=1.0 \mathrm{ppm}$.

y 0 treatment = no N applied before cover crop planting; N+treatment $=200 \mathrm{~kg} \cdot \mathrm{ha}^{-1}(179 \mathrm{lb} / \mathrm{acre})$ of N applied to sweet corn-cover crop followed.

${ }^{x}$ Within each year values in columns followed by different letters were significantly different $(P=0.05)$.

ered to be the level of residual plantavailable $\mathrm{N}$ in soil to a depth of $15 \mathrm{~cm}$ (Keeney and Nelson, 1982).

Significance of treatment main effects and interactions were determined by analysis of variance using the Statistical Analysis System, and significant $(P=0.05)$ differences among treatment means were determined using the least significant difference (SAS Institute, 1985).

\section{Results and discussion}

Interactions of vegetable tillage treatments with $\mathrm{N}$ and cover crop treatments were not significant. Thus, effects of $\mathrm{N}$ and cover crop treatments on yield, $\mathrm{N}$ concentration, total $\mathrm{N}$ content of cover crops, and residual soil $\mathrm{N}$ available to plants were determined for combined tillage treatments.

RESIDUAL-PLANT=AVALABLE-SOH-N- At the time of cover crop planting, residual plant-available soil $\mathrm{N}$ following corn was greater in the $\mathrm{N}+$ treatment than in the N0 treatment, and this difference was usually statistically significant for all cover crops (Table 1). In both $\mathrm{N}$ treatments residual available soil $\mathrm{N}$ was usually greatest with vetch and lowest with rye. This difference was statistically significant $(P=$ $0.05)$ in 1995 and in the $\mathrm{N}+$ treatment

Fig. 1. Cover crop biomass production obtained from (A) N+ treatments and (B) NO treatments. Within each bar group different letters denote significant $(P=\mathbf{0 . 0 5})$ differences. NO treatment $=$ no $\mathrm{N}$ applied before cover crop planting. $\mathrm{N}+$ treatment $=200 \mathrm{~kg} \cdot \mathrm{ha}^{-1}(179 \mathrm{lb} / \mathrm{acre})$ of $N$ applied to sweet corn-cover crop followed. (1.0 Mg.ha ${ }^{-1}=0.45 \mathrm{ton} /$ acre). in 1997. Thus, there were differences in residual available soil $\mathrm{N}$ among both cover crop and $\mathrm{N}$ treatments in soil to a depth of $15 \mathrm{~cm}$. Following field corn in September 1993, soil $\mathrm{N}$ available to the all 1994 cover crops was $10.8 \mathrm{mg} \cdot \mathrm{kg}^{-1}$ (10.8 ppm).
BHOMASSPRODUCTION-Following sweet corn receiving inorganic $\mathrm{N}$ fertilizer (i.e., $\mathrm{N}+$ treatment), biomass production of rye and biculture cover crops tended to be greater in 1995 than in 1996 or 1998 (Fig. 1A). Mild fall and winter temperatures apparently increased rye growth in 1995. Monthly mean air temperatures measured by the University of Kentucky Agricultural Weather Center in Lexington, Kentucky [ $40 \mathrm{~km}$ ( $25 \mathrm{mi})$ from the research site] from Oct. 1994 through April 1995 were above normal in all months except February. This was especially true in November, December, January, and March when mean monthly temperatures $( \pm$ deviation from normal) were $10.6(+3.3), 5.0(+2.8), 1.1$ $(+1.7)$, and $8.3(+1.7)^{\circ} \mathrm{C}$, respectively or $51.1(+5.9), 41.0(+5.0), 34.0$ $(+3.1)$, and $46.9(+3.1)^{\circ} \mathrm{F}$, respectively. Rye and biculture biomass production were similar in the $\mathrm{N}+$ treatment in all years (Fig. lA). However, in the N0 treatment, rye biomass production was significantly lower than
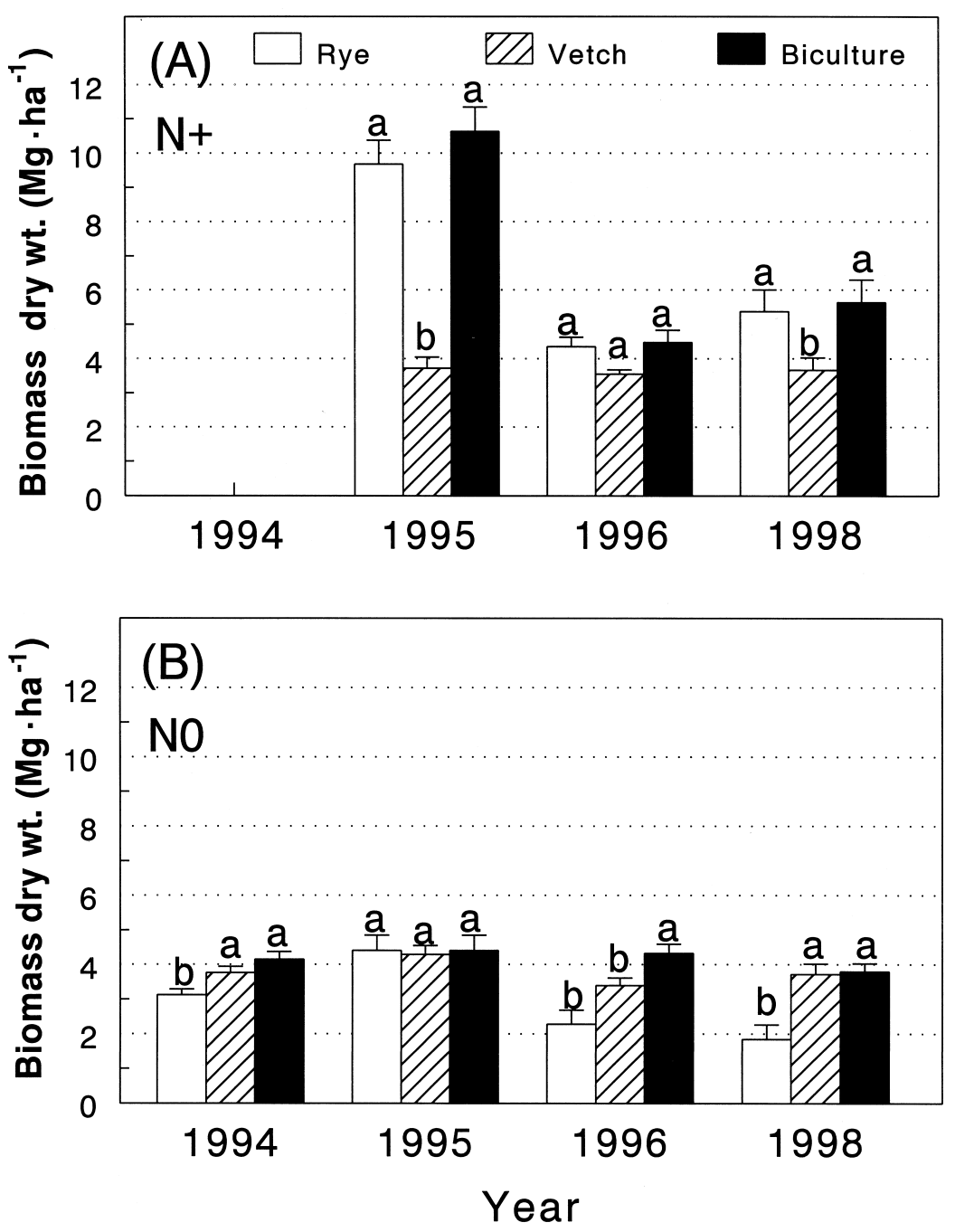

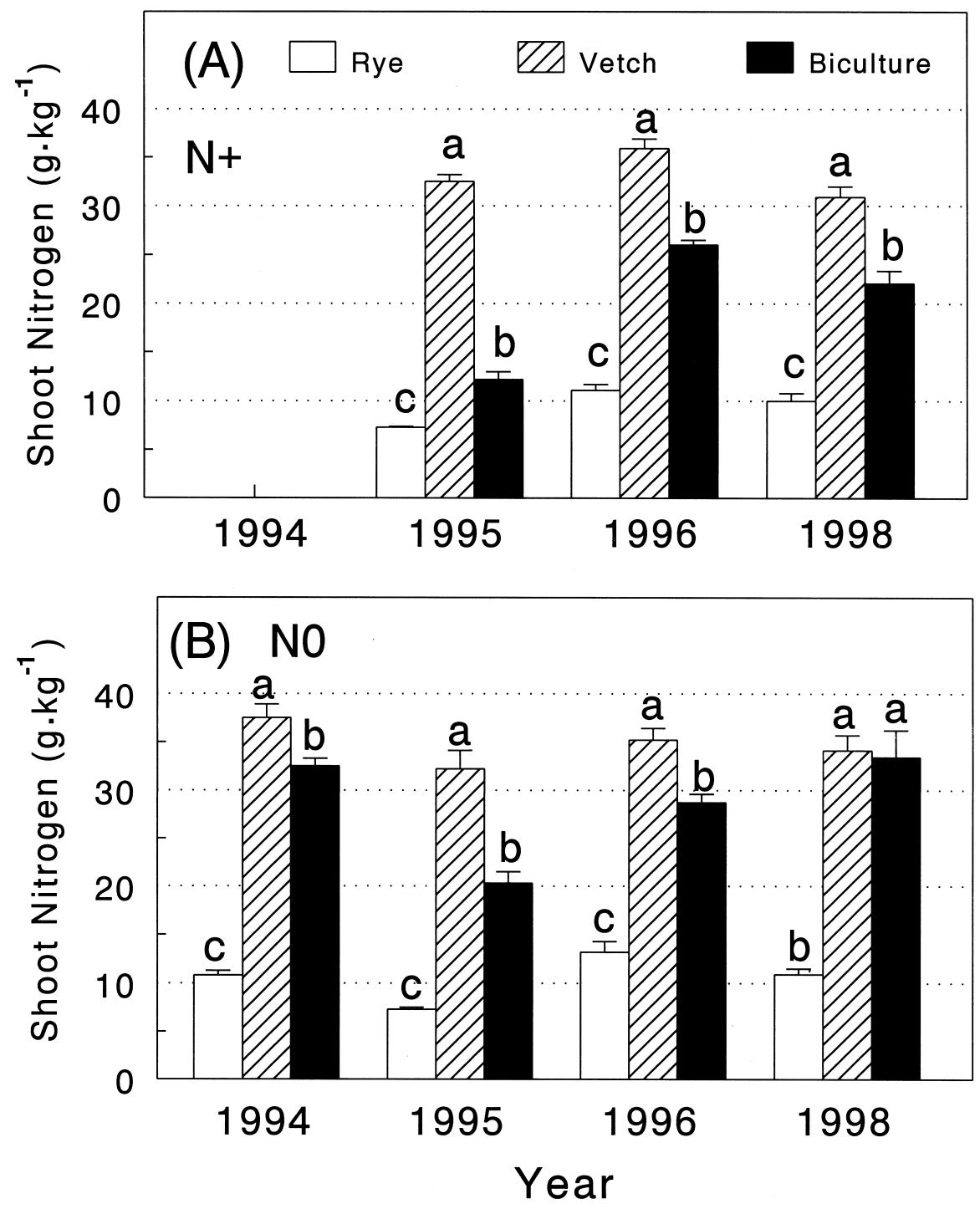

Fig. 2. Cover crop $N$ concentrations obtained from (A) $N+$ treatments and (B) No treatments. Within each bar group different letters denote significant $(P=$ 0.05 ) differences. N0 treatment $=$ no $\mathrm{N}$ applied before cover crop planting. $\mathrm{N}+$ treatment $=200 \mathrm{~kg} \cdot \mathrm{ha}^{-1}(179 \mathrm{lb} / \mathrm{acre})$ of $\mathrm{N}$ applied to sweet corn-cover crop followed. $\left(1.0 \mathrm{~g} \cdot \mathrm{kg}^{-1}=0.1 \%\right)$.

biculture biomass production in three of four years, indicating that rye was more dependent on residual N (Fig. 1B). In 1994, all cover crops followed field corn that had not been supplied with inorganic N. Vetch biomass production in the $\mathrm{N}+$ treatment was significantly lower than biomass production of rye or biculture cover crops in two of three years (Fig. 1A). Biomass production of all cover crops was similar in 1996 when growth was adversely affected by cold spring temperatures. Mean monthly air temperatures $\left( \pm{ }^{\circ} \mathrm{C}\right.$ deviation from normal) in March and April of 1996 were 3.9 ($2.8)$ and $10.6(-2.2)^{\circ} \mathrm{C}$, respectively or $39.0(-5.0)$ and $51.1(-4.0){ }^{\circ} \mathrm{F}$. Results indicated that biomass pro- duction of rye and biculture cover crops should exceed that of vetch in most years following an $\mathrm{N}$-fertilized summer vegetable crop. This agreed with findings for agronomic crops (Clark et al., 1994; Kuo et al., 1997a; Wagger, 1989), although vetch biomass production has exceeded that of rye when rye biomass production was relatively low (Blevins et al., 1990; Ebelhar et al., 1984).

Vetch biomass production in the N0 treatment was generally similar to that of the biculture cover crop and was significantly greater than rye biomass production in three of four years (Fig. 1A and B). Thus, without prior inputs of inorganic $\mathrm{N}$, vetch should produce dry matter in amounts gener- ally equivalent to rye and the biculture cover crop while fixing $\mathrm{N}_{2}$

Biomass production of rye and biculture cover crops was significantly $(P=0.05)$ lower in the N0 treatment than in the $\mathrm{N}+$ treatment, except for the biculture cover crop in the suboptimal year of 1996 (Fig. 1A and B). Thus, rye and biculture cover crops were able to effectively absorb (i.e., scavenge) residual $\mathrm{N}$ supplied as inorganic $\mathrm{N}$ fertilizer to a previous sweet corn crop. This finding agreed with the fact that residual available soil $\mathrm{N}$ levels were significantly greater in the $\mathrm{N}+$ treatment than in the N0 treatment (Table 1). Cover crop absorption of $\mathrm{N}$ decreases off-season $\mathrm{NO}_{3}$ leaching, thereby conserving soil $\mathrm{N}$ and reducing potential environmental pollution. Vetch biomass production in both $\mathrm{N}$ treatments remained relatively constant in all years and only varied from $3.5 \mathrm{Mg} \cdot \mathrm{ha}^{-1}$ (1.6 ton/acre) in 1996 to $4.0 \mathrm{Mg} \cdot \mathrm{ha}^{-1}$ (1.8 ton/acre) in 1995. Apparently vetch was able to symbiotically fix sufficient $\mathrm{N}_{2}$ in the N0 treatment to maintain normal growth. Vetch biomass production was similar (Abdul-Baki and Teasdale, 1997; Blevins et al., 1990; Decker et al., 1994; Kuo et al., 1997a; Smith et al., 1987) or smaller (Clark et al., 1994, 1995, 1997; Ebelhar et al., 1984) than biomass production reported by others.

SHOOT-N-CONCENTRATIONS: Shoot N concentrations of vetch were significantly greater than rye $\mathrm{N}$ concentrations, whereas biculture cover crop $\mathrm{N}$ concentrations were intermediate between those of vetch and rye (Fig. 2A and $\mathrm{B}$ ). Vetch and rye $\mathrm{N}$ concentrations were not affected by $\mathrm{N}$ treatments. In 1995 and 1998, N concentrations of the biculture cover crop were significantly $(P=0.05)$ greater in $\mathrm{N} 0$ treatments than in $\mathrm{N}+$ treatments due to a larger proportion of vetch in N0 treatments.

FөтAL-A-eONTEATS- The total N content of aboveground vetch cover crops was relatively constant and ranged from 120 to $150 \mathrm{~kg} \cdot \mathrm{ha}^{-1}$ (107 to $134 \mathrm{lb} /$ acre) for all years (Fig. $3 \mathrm{~A}$ and $\mathrm{B}$ ), approximately equal to the rate of inorganic $\mathrm{N}$ fertilizer recommended for most vegetables in Kentucky (Rowell et al., 1998). The $\mathrm{N}$ content of the biculture cover crop was similar to that of vetch in all years except for the N0 treatment in 1995. The lower shoot $\mathrm{N}$ concentrations of the biculture cover 

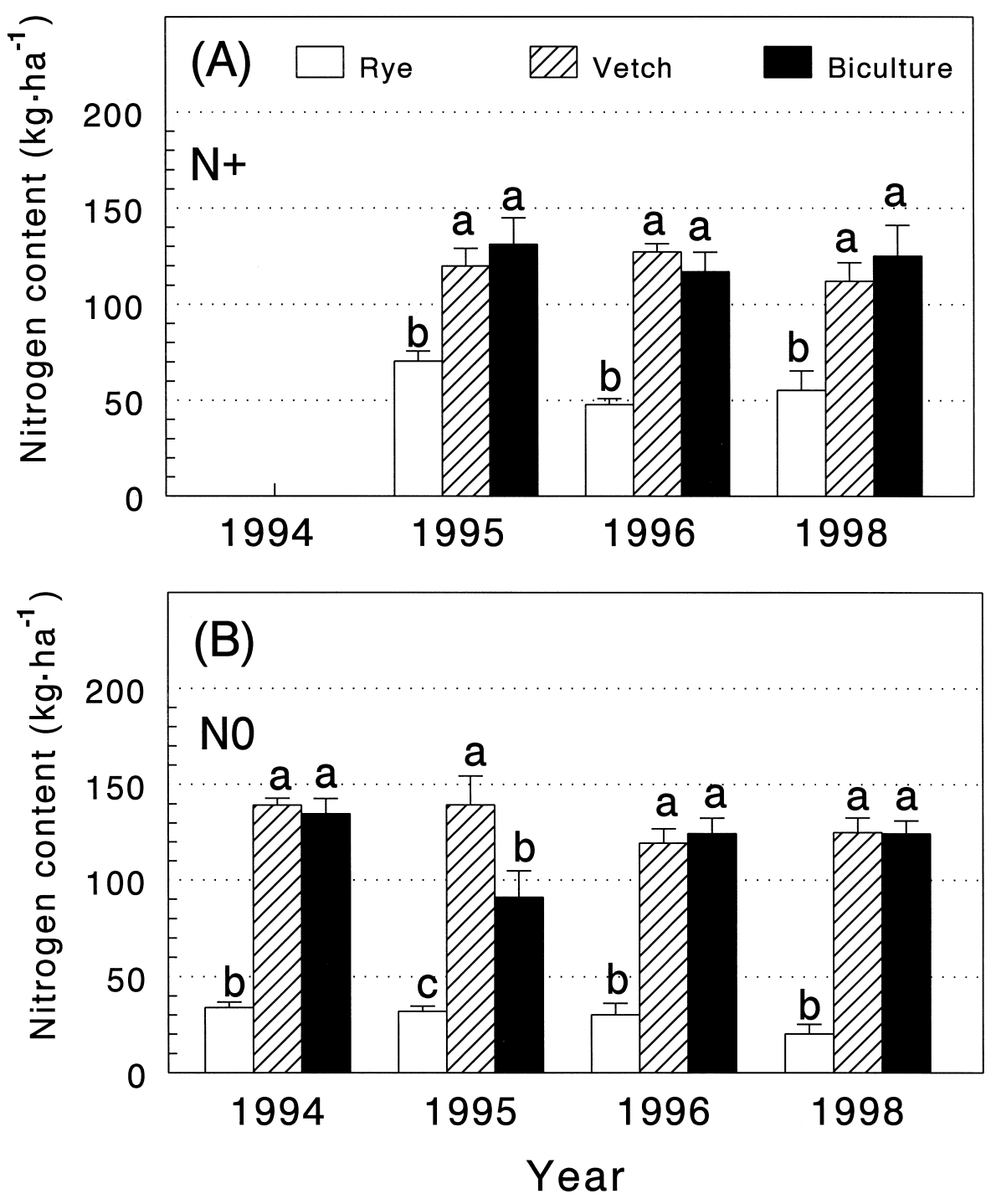

Fig. 3. Cover crop $N$ contents obtained from (A) $N+$ treatments and (B) No treatments. Within each bar group different letters denote significant $(P=$ 0.05 ) differences. N0 treatment $=$ no $N$ applied before cover crop planting. $N+$ treatment $=200 \mathrm{~kg} \cdot \mathrm{ha}^{-1}(179 \mathrm{lb} / \mathrm{acre})$ of $\mathrm{N}$ applied to sweet corn-cover crop followed. $\left(1.0 \mathrm{~kg} \cdot \mathrm{ha}^{-1}=0.89 \mathrm{lb} /\right.$ acre $)$.

crop (Fig. 2A and B) were generally offset by higher biculture biomass production (Fig. 1A and B). The $\mathrm{N}$ content of rye cover crops was significantly less than that of vetch or biculture cover crops in all years and was about $50 \mathrm{~kg} \cdot \mathrm{ha}^{-1}$ (about $45 \mathrm{lb} /$ acre) except for the $\mathrm{N}+$ treatment in 1995 (Fig. 3). Clark et al. $(1994,1997)$ reported similar results with field corn, although earlier kill dates were used.

The $\mathrm{N}$ contents of vetch and biculture cover crops were not affected by $\mathrm{N}$ treatments, except in 1995 when the $\mathrm{N}$ content of the biculture cover crop was significantly $(P=0.05)$ greater in the $\mathrm{N}+$ treatment than in the N0 treatment (Fig. 3A and B). In contrast, rye $\mathrm{N}$ content was significantly $(P=$ ably recovered about $10 \mathrm{~kg} \cdot \mathrm{ha}^{-1}(9 \mathrm{lb} /$ acre) of $\mathrm{N}$ in our study. Thus, the average rate of residual $\mathrm{N}$ recovery by roots plus shoots was estimated as 40 $\mathrm{kg} \cdot \mathrm{ha}^{-1}(36 \mathrm{lb} / \mathrm{acre})$.

BicULtURE-COVER-CROP-Vetch dry matter production, foliar $\mathrm{N}$ concentration, and $\mathrm{N}$ content exceeded those of rye in the N0, biculture cover crop treatment (Table 2). Differences were significant in all years except for biomass production in 1995. Vetch predominated under conditions of low $\mathrm{N}$ availability because of its ability to fix atmospheric $\mathrm{N}_{2}$ In the N0 treatment, the percentage of vetch dry matter in the biculture cover crop averaged $71 \%$ for all years combined. In contrast to the N0 treatment, vetch biomass production in the $\mathrm{N}_{+}$ biculture cover crop treatment was similar or significantly less than rye biomass production, indicating that rye competed more effectively with vetch as $\mathrm{N}$ availability increased (Table 2). Percent vetch dry matter in the biculture cover crop was only $34 \%$ in the $\mathrm{N}+$ treatment for all years combined. Consequently, biculture $\mathrm{N}$ concentrations were significantly $(P=0.05)$ greater in the N0 than $\mathrm{N}+$ treatment in 1995 and 1998 (Fig. $2 \mathrm{~A}$ and $\mathrm{B})$. The $\mathrm{N}$ contents of rye and vetch were variable in the $\mathrm{N}+$ biculture treatment. Rye $\mathrm{N}$ concentrations tended to be greater in biculture treatments than in rye monocultures, particularly in N0 treatments in 1994 and 1998 (Fig. 2 , Table 2). This was true even though vetch and rye components of the biculture cover crop were meticulously separated at sampling. Sullivan et al. (1991) and Rannells and Wagger (1996) also reported that rye $\mathrm{N}$ concentrations were greater in vetch/rye bicultures than in rye monocultures. These data suggested that $\mathrm{N}$ transfer from vetch to rye occurred in the biculture treatment. However, monoculture rye $\mathrm{N}$ concentrations were not affected by addition of inorganic $\mathrm{N}$ to a previous crop that increased rye biomass production (Figs. $\mathrm{l}$ and 2), indicating that only biomass production, and not $\mathrm{N}$ concentration, of rye was increased as $\mathrm{N}$ availability became greater. Thus, increased rye $\mathrm{N}$ concentrations with vetch may not necessarily demonstrate $\mathrm{N}$ transfer.

It was hoped that the $\mathrm{N}$ content and biomass production of the biculture cover crop would adjust to needs of individual soils through vetch and rye competition as suggested by Clark et al. (1994). The ratio of rye to vetch biomass production in the 
Table 2. Effects of inorganic nitrogen $(\mathrm{N})$ applied to a previous crop on a vetch/rye biculture winter cover crop.

\begin{tabular}{|c|c|c|c|c|c|c|c|c|}
\hline \multirow{3}{*}{$\begin{array}{l}\text { Cover } \\
\text { crop }\end{array}$} & \multicolumn{4}{|c|}{ No treatment ${ }^{\mathrm{z}}$} & \multicolumn{4}{|c|}{$\mathrm{N}+$ treatment $^{\mathrm{y}}$} \\
\hline & \multicolumn{2}{|c|}{ Dry matter } & \multirow{2}{*}{$\begin{array}{l}\text { Shoot N } \\
\left(\mathrm{g} \cdot \mathrm{kg}^{-1}\right)^{\mathrm{w}}\end{array}$} & \multirow{2}{*}{$\begin{array}{l}\text { N content } \\
\left(\mathbf{k g} \cdot \mathrm{ha}^{-\mathbf{l}}\right)^{\mathbf{v}}\end{array}$} & \multicolumn{2}{|c|}{ Dry matter } & \multirow{2}{*}{$\begin{array}{c}\text { Shoot N } \\
\left(\mathrm{g} \cdot \mathrm{kg}^{-1}\right)\end{array}$} & \multirow{2}{*}{$\begin{array}{c}\text { N content } \\
\left(\mathrm{kg} \cdot \mathrm{ha} \mathrm{a}^{-1}\right)\end{array}$} \\
\hline & Mg.ha $^{-1 x}$ & $\%$ of total & & & Mg.ha $^{-1}$ & $\%$ of total & & \\
\hline Rye & $0.85 b^{u}$ & 20 & $20.6 \mathrm{~b}$ & $17.4 \mathrm{~b}$ & & & & \\
\hline \multirow[t]{2}{*}{ Vetch } & $3.30 \mathrm{a}$ & 80 & $35.6 \mathrm{a}$ & $117.4 \mathrm{a}$ & & & & \\
\hline & \multicolumn{8}{|c|}{1995} \\
\hline Vetch & $2.41 \mathrm{a}$ & 55 & $29.7 \mathrm{a}$ & $72.1 \mathrm{a}$ & $1.21 \mathrm{~b}$ & 11 & $30.6 \mathrm{a}$ & $36.9 \mathrm{~b}$ \\
\hline & \multicolumn{8}{|c|}{1996} \\
\hline Rye & $1.60 \mathrm{~b}$ & 37 & $15.8 \mathrm{~b}$ & $25.4 \mathrm{~b}$ & $2.15 \mathrm{a}$ & 48 & $15.9 \mathrm{~b}$ & $34.7 \mathrm{~b}$ \\
\hline Vetch & $2.73 \mathrm{a}$ & 63 & $36.2 \mathrm{a}$ & $99.0 \mathrm{a}$ & $2.33 \mathrm{a}$ & 52 & $37.2 \mathrm{a}$ & $86.4 \mathrm{a}$ \\
\hline & \multicolumn{8}{|c|}{1998} \\
\hline Rye & $0.55 \mathrm{~b}$ & 14 & $18.1 \mathrm{~b}$ & $8.5 \mathrm{~b}$ & $3.46 \mathrm{a}$ & 61 & $13.7 \mathrm{~b}$ & $51.1 \mathrm{a}$ \\
\hline
\end{tabular}

biculture cover crop was expected to vary directly with $\mathrm{N}$ availability, resulting in maximum $\mathrm{N}_{2}$ fixation in $\mathrm{N}$ deficient soils. Conversely, in N-sufficient soils both the rye to vetch yield ratio and total biculture cover crop biomass production should be higher than in N-deficient soils, resulting in maximum organic matter accumulation. In this study yield responses of the biculture cover crop and species competition within the biculture cover crop occurred as anticipated in N0 and $\mathrm{N}+$ treatments (Fig. 1, Table 2). In the No treatment, the percentage of biculture biomass comprised of vetch was significantly greater than that of rye, whereas this was not true in the $\mathrm{N}+$ treatment (Table 2). Also, biomass production of the biculture cover crop was significantly $(P=0.05)$ greater in the $\mathrm{N}+$ than in the N0 treatment, except in 1996 (Fig. 1). However, the $\mathrm{N}$ content of the biculture cover crop was not higher in the N0 treatment than in the $\mathrm{N}+$ treatment as anticipated (Fig. 3). The biculture cover crop may still supply more $\mathrm{N}$ to vegetables under $\mathrm{N}$-deficient conditions because it should contain more vetch compared to $\mathrm{N}$-sufficient conditions. Vetch has a lower $\mathrm{C}: \mathrm{N}$ ratio than rye, and consequently net soil $\mathrm{N}$ mineralization and $\mathrm{N}$ availability are greater following vetch than rye (Allison, 1966; Clark et al., 1994, 1997).

FHLagetKHL-DATE:EFFECTs: Compared to the treatment in which cover crops were incorporated into the soil using tillage, the additional $8 \mathrm{~d}$ of vetch growth consistently resulted in increased vetch biomass production (Table 3). These yield increases were significant in 1994 and 1995. However, vetch shoot $\mathrm{N}$ concentrations were significantly reduced by the additional growth associated with the time delay, in agreement with the findings of Wagger (1989) and Clark et al. $(1994,1995,1997)$ (Table 3$)$. Consequently, although the 8-d delay increased vetch biomass production, vetch $\mathrm{N}$ content was not affected. Thus, farmers may not acquire more fixed $\mathrm{N}_{2}$ by allowing vetch to grow past midMay in Kentucky. Clark et al. (1994, 1995, 1997) obtained increased amounts of fixed $\mathrm{N}_{2}$ when vetch kill dates were delayed from April to early or mid-May in Maryland, indicting

Table 3. Response of hairy vetch to $8 \mathrm{~d}$ of additional spring growth in no-till compared with tilled treatments.

\begin{tabular}{|c|c|c|c|c|}
\hline \multirow[b]{2}{*}{$\underline{\text { Year }^{z}}$} & \multirow[b]{2}{*}{$\begin{array}{c}\text { Vegetable } \\
\text { tillage }\end{array}$} & \multicolumn{3}{|c|}{ Vetch cover crop } \\
\hline & & $\begin{array}{c}\text { Dry matter } \\
\left(\text { Mg.ha }^{-1}\right)^{y}\end{array}$ & $\begin{array}{l}\text { Shoot N } \\
\left(g \cdot k^{-1}\right)^{x}\end{array}$ & $\begin{array}{l}\mathbf{N} \text { content } \\
\left(\mathrm{kg} \cdot \mathrm{ha}^{-1}\right)^{\mathrm{w}}\end{array}$ \\
\hline \multirow[t]{2}{*}{1994} & Tilled & $3.26^{* * *}$ & $42.0^{\star * *}$ & 137 \\
\hline & No-till & 4.19 & 33.6 & 141 \\
\hline \multirow[t]{2}{*}{1995} & Tilled & $3.76^{* * *}$ & $34.2^{\star \star}$ & 130 \\
\hline & No-till & 4.24 & 30.4 & 129 \\
\hline \multirow[t]{2}{*}{1996} & Tilled & 3.37 & $37.3^{\star *}$ & 126 \\
\hline & No-till & 3.58 & 33.9 & 121 \\
\hline
\end{tabular}

zIn 1998, the same kill date was used in both tillage treatments.

y $1.0 \mathrm{Mg} \cdot \mathrm{ha}^{-1}=0.45 \mathrm{ton} /$ acre.

${ }^{\mathrm{x}} 1.0 \mathrm{~g} \cdot \mathrm{kg}^{-1}=0.1 \%$

${ }^{\mathrm{w}} 1.0 \mathrm{~kg} \cdot \mathrm{ha}^{-1}=0.89 \mathrm{lb} /$ acre.

${ }^{\star * *},{ }^{\star * \star}$ Tillage difference for that year is significant at $P=0.10$ or 0.05 . that kill date delays earlier in the season should increase vetch $\mathrm{N}$ content at locations near this geographical latitude in the eastern United States, including Kentucky. Also, Wagger (1989) reported increased cover crop biomass production and $\mathrm{N}$ content by delaying the kill date from late-March until mid-April in North Carolina, whose growing season begins earlier than in Kentucky or Maryland. No significant effects of kill dates were detected for rye and biculture cover crops in this study. It was concluded that prior fertilization of sweet corn with inorganic $\mathrm{N}$ affected various cover crops differently and that delaying vetch kill dates in mid-May increased vetch biomass production but did not affect vetch $\mathrm{N}$ content. 


\section{Literature cited}

Abdul-Baki, A.A., J.R. Stommel, A.E. Watada, J.R. Teasdale, and R.D. Morse. 1996a. Hairy vetch mulch favorably impacts yield of processing tomatoes. HortScience 31:338-340

Abdul-Baki,A.A., J.R. Teasdale, R.F Korcak, D.J. Chitwood, and R.N. Huettel. 1996b. Fresh market tomatoe production in a lowinput alternative system using cover crop mulch. HortScience 31:65-69.

Abdul-Baki, A.A. and J.R. Teasdale. 1997. Snap bean production in conventional tillage and in no-till hairy vetch mulch. HortScience. 32:1191-1193.

Abdul-Baki,A.A., J.R. Teasdale, R.F Korcak. 1997. Nitrogen requirements of fresh-market tomatoes on hairy vetch and black polyethylene mulch. HortScience 32:217-221.

Allison, F.E. 1966. The fate of nitrogen applied to soils. Adv. Agron. 18:219-258.

Blevins, R.L. W.W. Frye, P.L. Baldwin, and S.D. Robertson. 1990. Tillage effects on sediment and soluble nutrient losses from a Maury silt loam soil. J. Environ. Qual. 19:683-686.

Bollero, G.A. and D.G. Bullock. 1994. Cover cropping systems for the central corn belt. J. Prod. Agr. 7:55-58.

Brumfield, R.G. 1996. Sustainable horticulture: An overview. Hort Technolgy 6:352354 .

Burket, J.Z. D.D. Hemphill, and R.P. Dick. 1997. Winter cover crops and nitrogen management in sweet corn and broccoli rotations. HortScience 32:664-668.

Clark, A.J.,A.M. Decker, and J.J. Meisinger. 1994. Seeding rate and kill date effects on hairy vetch-cereal rye cover crop mixtures for corn production. Agron. J. 86:10651070 .

Clark, A.J., A.M. Decker, and J.J. Meisinger, R. Mulford, and M.S. McIntosh. 1995. Hairy vetch kill date effects on soil water and corn production. Agron. J. 87:579-585.

Clark, A.J., A.M. Decker, and J.J. Meisinger, and M.S. McIntosh. 1997. Kill date of vetch, rye, and a vetch-rye mixture I. Cover crop and corn nitrogen. Agron. J. 89:427434 .

Decker, A.M., A.J. Clark, J.J. Meisinger, R. Mulford, and M.S. McIntosh. 1994. Legume cover crops for no-till corn production. Agron. J. 86:126-135.

Drost, D., G. Long, and K. Hales. 1997. Utah's vegetable growers: Assessing sustainable agriculture. HortTechnology 7:445450 .

Ebelhar, S.A., W.W. Frye, and R.L. Blevins.
1984. Nitrogen from legume cover crops. Agron. J. 76:51-55.

Hanson J.C., C.S. Kauffman, and A. Schauer. 1995. Attitudes and practices of sustainable farmers, with applications to designing a sustainable agriculture extension program. J. Sustainable Agr. 6:135-156.

Holderbaum, J.F., A.M. Decker, J.J. Meisinger, F.R. Mulford, and L.R.Vough. 1990. Fall-seeded legume cover corps for no-tillage corn in the humid East. Agron. J. 82:117-124.

Hoyt, G.D. 1999. Tillage and cover residue affects on vegetable yields. HortTechnology 9:351-358

Hoyt, G.D., D.W. Monks, and T.J. Monaco. 1994. Conservation tillage for vegetable production. HortTechnology 4:129135.

Hoyt, G.D. and J.F. Walgenbach. 1995. Pest evaluation in sustainable cabbage production systems. HortScience 30:10461048

Infante, M.L. and R.D. Morse. 1996. Integration of no-tillage and overseeded legume living mulches for transplanted broccoli production. HortScience 31:376-380.

Johnson, A.M. and G.D. Hoyt. 1999. Changes to the soil environment under conservation tillage. Hort Technology 9:380393.

Keeney, D.R. and D.W. Nelson. 1982. Nitrogen-Inorganic forms, p. 643-698. In A.L. Page (ed.). Methods of soil analysis. Part 2. Chemical and microbiological properties. Amer. Soc. Agron. Madison, Wis.

Knavel, D.E. and J.W. Herron. 1986. Response of vegetable crops to nitrogen rates in tillage systems with and without vetch and ryegrass. J. Amer. Soc. Hort. Sci. 111:502-507.

Knavel, D.E., J. Ellis, and J. Morrison. 1977. The effects of tillage systems on the performance and elemental absorption by selected vegetable crops. J. Amer. Soc. Hort. Sci. 102:323-327.

Kuo, S., U.M. Sainju, and E.J. Jellum. 1997a. Winter cover crop effects on soil organic carbon and carbohydrate in soil. Soil Sci. Soc. Amer. J. 61:145-152

Kuo, S., U.M. Sainju, and E.J. Jellum. 1997b. Winter cover cropping influence on nitrogen in soil. Soil Sci. Soc. Amer. J. 61:13921399.

Mwaja, V.N., J.B. Masiunasi, and C.E. Eastman. 1996. Rye (Secale cereale L.) and hairy vetch (Vicia villosa Roth) intercrop management in fresh-market vegetables. J. Amer. Soc. Hort. Sci. 121:586-591.

Peet, M. 1996. Sustainable practices for vegetable production in the South. Focus Publishing, R. Pullins Co., Newburyport, MA. p. 3-21.

Peterson, K.L., H.J. Mack, and R.H. Cuenca. 1985. Effect of tillage on the crop-water production function of sweet corn in western Oregon. HortScience 20:901-903.

Rannells, N.N. and M.G. Wagger. 1996. Nitrogen release from grass and legume cover crop monocultures and bicultures Agron. J. 88:777-782.

Rannells, N.N. and M.G. Wagger. 1997. Grass-legume bicultures as winter annual cover crops Agron. J. 89:659-665.

Rasnake, M., W. Dunwell, and J. Reid. 1996. Winter cover crops for Kentucky gardens and fields. Univ. Ky. Coop. Ext. Publ. ID-113.

Roberts, W., J. Duthie, J. Edelson, B. Cartwright, J. Shrefler, and N. Roe. 1999. Limitations and possibilities for some conservation tillage systems with vegetable crops in the southern plains of the United States. HortTechnology 9:359-365.

Rowell B., J. Strang, T. Jones, R. Bessin, W. Nesmith, L.A. Weston, and B. Thom. 1998. Commercial vegetable crop recommendations. Univ. Ky. Coop. Ext. Serv. ID-36.

Statistical Analysis System Institute. 1985. SAS user's guide: Statistics. version 5 ed. SAS, Cary, N.C.

Scarphol, B.J., and K.A. Corey. 1987. Response of snap beans to tillage and cover crop combinations. J. Amer. Soc. Hort. Sci. 112:936-941.

Schonbeck, M., P., Elder, and R. Degregorio. 1995. Winter annual cover crops for the home garden. J. Sustain. Agr. 6:29-53.

Shipley, P.R., J.J. Meisinger, and A.M. Decker. 1992. Conserving residual corn fertilizer nitrogen with winter cover crops. Agron. J. 84:869-876.

Singogo, W., W.J. Lamont, Jr., and Charles W. Marr. 1996. Fall-planted cover crops support good yields of muskmelons. HortScience 31:62-64.

Smith, S.M., W.W. Frye, and J.J. Varco. 1987. Legume winter cover crops. Adv. Soil Sci. 7:96-139.

Sullivan, P.G., D.J. Parish, and J.M. Luna. 1991. Cover crop contributions to N supply and water conservation in corn production. Amer. J. Alternative Agr. 6:106-113.

Wagger, M.G. 1989. Time of desiccation effects on plant composition and subsequent nitrogen release from several winter annual cover crops. Agron. J. 81:236-241. 